Agroforestry Systems 3: 275-295.

() 1985 Martinus Nijhoff/Dr W. Junk Publishers, Dordrecht. Printed in the Netherlands.

\title{
Babassu palm in the agroforestry systems in Brazil's Mid-North region
}

\author{
P.H. MAY ${ }^{1}$, A.B. ANDERSON ${ }^{2}$, J.M.F. FRAZÃO ${ }^{3}$ and M.J. BALICK ${ }^{4}$ \\ ${ }^{1}$ Department of Agricultural Economics, Cornell University Warren Hall, Ithaca, NY \\ 14853, U.S.A. ${ }^{2}$ Botany Department, Museu Paraense Emílio Goeldi, Av. Magalhães \\ Barata, 376, C.P. 399, Belém, Pará, 66.000, Brazil ${ }^{3}$ Programa Nacional de Pesquisas \\ do Babaçu, EMBRAPA, UEPAE-Teresina, C.P. 01, Teresina, Piauí, 64.000, Brazil \\ ${ }^{4}$ Institute of Economic Botany, New York Botanical Garden, Bronx, NY 10458, USA
}

Key words: Babassu palms, Orbignya, Palmae, vegetable oil, charcoal, land tenure, Northeast Brazil, pasture expansion, shifting cultivation

\begin{abstract}
Babassu palms (Orbignya spp.) cover nearly $200,000 \mathrm{~km}^{2}$ in Brazil, providing cash income, fuel, fibre, edible oil and food to a large number of tenant farm households. Babassu is closely integrated within pastoral and shifting cultivation systems of Mid-North Brazil. In pastures, babassu provides shade for cattle, aids soil moisture retention, produces organic matter, generates supplementary farm income at little cost, and offers year-round employment. On the other hand, the persistence of juvenile palms reduces pasture grass productivity due to plant competition, and therefore there is a trend to eradicate babassu through clearcutting and understorey suppression. At moderate densities of less than 100 individuals per ha, mature babassu palms in cropland do not appear to harm crop productivity. In such cases, palms are thinned and leaves of the remaining ones are cut back, supplying fuel for the burn and nutrients to the soil. However, reduced fallow cycles due to pasture conversion threaten babassu as well as crop productivity.
\end{abstract}

Resumo. Palmeiras de babaçu (Orbignya spp.) occorrem em quase $200.000 \mathrm{~km}^{2}$ no Brasil, proporcionando renda em dinheiro, combustível, fibras, óleo e alimentos para cerca de quinhentas mil famílias de pequenos produtores rurais, a maioria arrendatários ou posseiros. $\mathrm{O}$ babaçu aparece integrado dentro de sistemas de produção pastorís e de agricultura migratória no Meio Norte do Brasil. Nas pastagens, o babaçu provế sombra para o gado, ajuda na retenção da umidade no solo, produz matéria orgânica, gera renda suplementar com investimento mínimo, e oferece condiçōes para fixar a força de trabalho durante a entressafra dos produtos agrícolas. A presença de palmeiras juvenís, porém, reduz a produtividade dos pastos devido a competição, o que leva os criadores de gado a erradicar o babaçu, suprimindo tanto as palmeiras juvenís, como as palmeiras adultas.

No que diz respeito à agricultura migratória, o babaçu adulto em densidades moderadas, ou seja, até 100 indivíduos por hectare, aparentemente não reduz a produtividade das culturas anuais. Nestes casos, parte das palmeiras são desbastadas e as folhas das restantes cortadas, proporcionando combustível para a queima e nutrientes para o solo. No entanto, a redução nos ciclos de descanso devido à conversão das terras agrícolas em pastagens ameaça a produtividade quer do babaçu quer das próprias culturas.

Contribution No. 11 of the series on Agroforestry System Descriptions under ICRAF's AF Systems Inventory Project, funded partially by the United States Agency for International Development - USAID (see Agroforestry Systems 1 (3), 269-273, for project details). Series editor: P.K.R. Nair, ICRAF. 


\section{Introduction}

The babassu palm (Orbignya phalerata Mart.*) and related species occur widely in Brazil, Bolivia, Colombia, Mexico and other parts of Latin America. Kernels extracted manually from babassu's thick-shelled fruit are a source of lauric oil having both edible and industrial uses. Figure 1 shows the distribution of babassu in Brazil. Over $80 \%$ of babassu kernel marketed in Brazil comes from the Northeast states of Maraninão and Piauí, known as the MidNorth region, which produces about $200,000 \mathrm{t}$ of kernels annually (Table1). A major industry that expresses oil from these kernels is concentrated in the

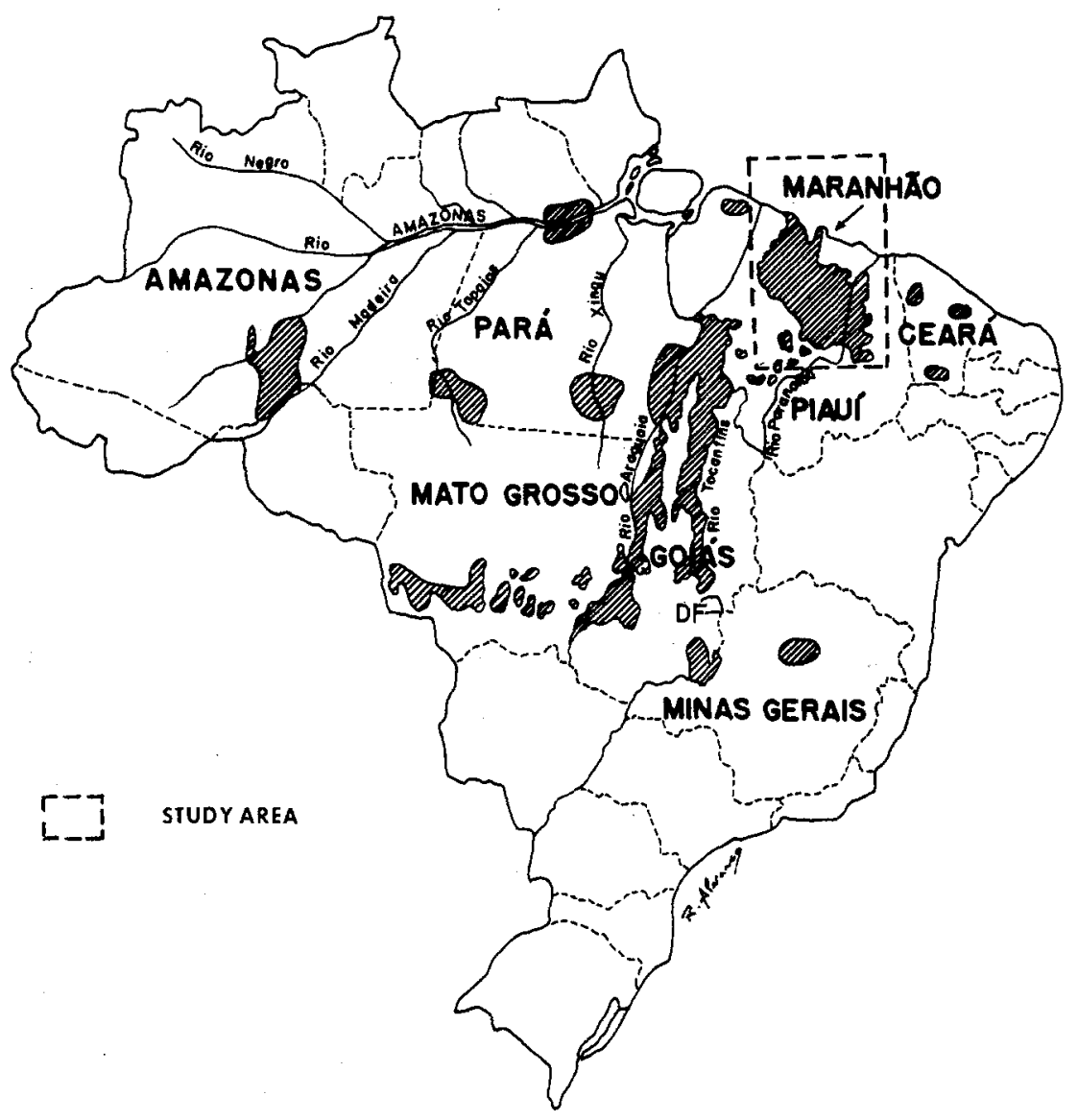

Figure 1. Areas of occurrence of babassu palms in Brazil. States where babassu occurs are labelled. Heavy dotted line encloses the Mid-North region. Drawn by R. Alvares based on maps in [3] and [14].

*Also referred to in the scientific and popular literature as Orbignya martiana, $O$. barbosiana, $O$. spp. and other names. 
Table 1. Area of babassu stands and their commercial exploitation in the Mid-North region of Brazil

\begin{tabular}{lrrrrr}
\hline Region & \multicolumn{2}{c}{ Area of stand occurrence } & & \multicolumn{2}{c}{ Kernels marketed (1980) } \\
\cline { 2 - 3 } \cline { 2 - 3 } & $\mathrm{km}^{2}$ & $\%$ & & metric tons & $\%$ \\
\hline Maranhão & 103,040 & 53 & 183,455 & 73 \\
Piauí & 19,780 & 10 & 20,214 & 8 \\
Mid-North & & & & 81 \\
(subtotal) & 122,820 & 63 & 213,669 & 19 \\
Other areas & 73,550 & 37 & 37,282 & 100 \\
Brazil & 196,370 & 100 & 250,951 & \\
\hline
\end{tabular}

Sources: $[11,14]$

region. In 1980, over 30 oil factories operated in Maranhão alone [1]. Kernels constitute less than $8 \%$ of the fruit by weight although strains containing up to $17 \%$ kernel have been encountered. The remaining parts can be used industrially for production of charcoal, feedmeals and other by-products for which efforts have been initiated recently. These technological developments permit breaking babassu fruits mechanically and separation of their components for further processing.

Babassu kernels are third only to timber and rice in gross agricultural product value in Maranhão, where the economy relies on the primary sector for over $60 \%$ of its GDP. The palm also provides non-market goods and services to the rural population of the Mid-North region, in the form of fuel, fibre and food.

Babassu palms are seldom planted, but are managed within regional agroforestry systems, performing a vital role in the local economy.

\section{General description of the area}

\subsection{Geographical location}

The babassu zone of Mid-North Brazil includes portions of Maranhão north of $6^{\circ} \mathrm{S}$., and east of $46^{\circ} \mathrm{W}$., and of Piaui west of $42^{\circ} \mathrm{W}$., bounded on the north by the Atlantic Ocean (Figure 2). Although most of the babassu zone is under $200 \mathrm{~m}$ in altitude, palms are found up to $1000 \mathrm{~m}$. Babassu stands occupy over $120,000 \mathrm{~km}^{2}$ in this region, some on upland sites and others in galleries along valley bottoms.

\subsection{Historical evolution}

The indigenous tribes which originally inhabited the region identified their territorial rights with stands of fruit-bearing palms such as babassu, which provided fuel and fibre as well as a reserve against famine [16]. After colonization by Europeans, the region became an important producer of sugarcane and later cotton on slave plantations. After slavery was abolished in 1888, 


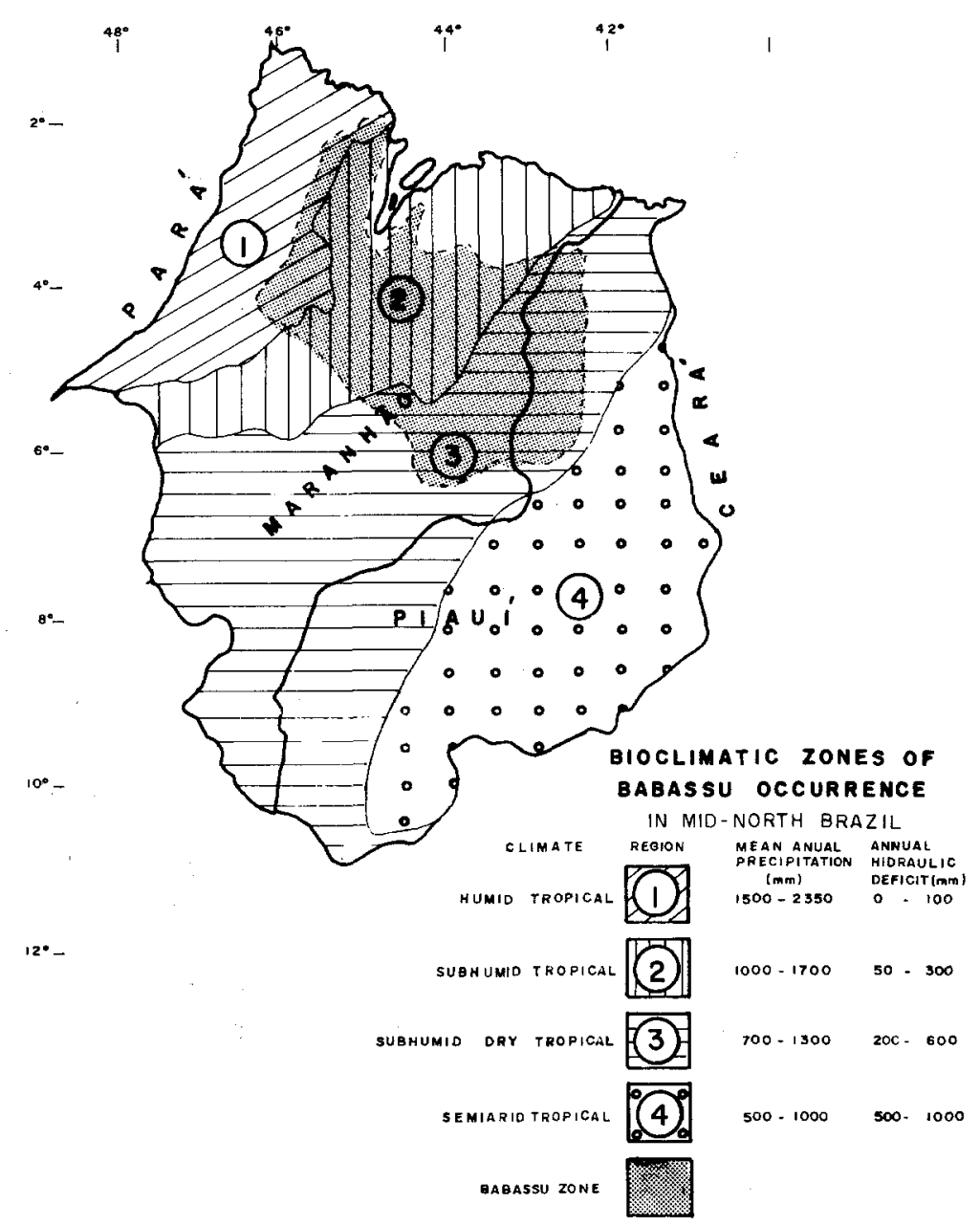

Figure 2. Bioclimatic zones of babassu occurrence in Mid-North Brazil. Drawn by R.M. Lima after map in [9].

the plantation economy collapsed; freed slaves and new immigrants established homesteads in unsettled areas where hunting, gathering and fishing complemented subsistence agriculture. The settlers relied on babassu palms for food, fuel and shelter. Since the 1920s, a steadily growing market for babassu kernels has contributed to inhabitants' cash incomes.

Most residents today are landless tenant farmers on properties controlled by a relatively small number of people (in Maranhão, $85 \%$ of the land is owned by $15 \%$ of the enterprises [10]). The landless pay in-kind for the right to live on the property and use the land for shifting cultivation, and must sell babassu kernels they extract to the landowner or his agent. 


\subsection{Biophysical environment}

The Mid-North babassu zone is one of bioclimatic transition between Amazonian humid evergreen forests, savannas and woodlands (Cerrado), and semi-arid thorn scrub (Caatinga) of the Northeast. Annual mean temperatures range from $20-27^{\circ} \mathrm{C}$. Seasonal rainfall varies within three pluviometric regimes (Figure 2) from 700-2100 $\mathrm{mm}$ annually [9], 90\% of which falls unimodally from January to June.

Within the eastern dry 'Cerrado' belt $(700-1300 \mathrm{~mm})$ babassu occurs in galleries along river banks whose alluvial sandy clays retain water during a 6-8 month dry season. Soils of the upland Cerrado are deeply-weathered sandy laterites. Babassu is sparse on these dry lands, whose vegetation consists mainly of leguminous trees and scrub with carnauba (Copernicia prunifera) palms appearing over unimproved range.

A more humid sub-region $(1500-1800 \mathrm{~mm}$ ) lies to the west, where alluvial deposits from three major rivers create well-structured alfisols with moderate $\mathrm{P}$ and $\mathrm{N}$ content, high cation exchange capacity and base saturation. Over $80 \%$ of land area is covered with babassu palms in this 'Cocais' (palm forest) sub-region.

The 'Pre-Amazonic' zone (1600-2100 mm) lies on Maranhão's western frontier. Patches of tropical moist forest are interspersed with young secondary forest (Capoeira). Babassu is present in the former and dominant in the latter. As rapidly accelerating settlement encroaches on the Pre-Amazonic zone, dense babassu stands spread into the frontier.

\subsection{Land use systems}

1.4.1 Agriculture. In the Cerrado, mixed enterprise farms involve shifting cultivation within bottomland stands of babassu with beef cattle grazed on upland unenclosed range. In the Cocais and Pre-Amazonic regions, babassu and primary forests are being converted to improved pasture and some mechanized crop production. There are many dairy farms in the Cocais. Construction of paved highways in this region has strengthened rural-urban communications, yet most babassu zone farmland remains inaccessible to vehicles during the rainy season.

1.4.2 Forestry. Hardwood timbers from native forests are extracted to defray expenses of clearing new pasture and cropland at the frontier. National reforestation incentives have promoted landowners to plant eucalypts (Eucalyptus urophila, E. braciana, and E. exta) on poor Cerrado soils. Bamboo (Bambusa vulgaris) and pine (Pinus caribaea) are being planted in lowland areas cleared of babassu. Cashew (Anacardium occidentale) and coconut (Cocos nucifera) are also being established. Total area reforested between $1978-1983$ is over 35000 ha in Maranhão alone (Table 2).

The government has supported reforestation efforts using babassu in 
Table 2. Area reforested per year by species: Maranhão

\begin{tabular}{|c|c|c|c|c|c|c|}
\hline \multirow[b]{2}{*}{ Year } & \multicolumn{5}{|c|}{$\begin{array}{l}\text { (Hectares) } \\
\text { Species }\end{array}$} & \multirow[b]{2}{*}{ Total } \\
\hline & Cashew & Coconut & Eucalypts & Pine & Bamboo & \\
\hline 1978 & 250 & - & - & - & - & 250 \\
\hline 1979 & 1,100 & 250 & - & - & _- & 1,350 \\
\hline 1980 & 1,900 & 1,400 & 200 & - & - & 3,500 \\
\hline 1981 & 1,710 & 930 & 2,800 & 1,600 & 1,500 & 8,540 \\
\hline 1982 & 3,088 & 870 & 5,920 & 2,400 & 1,500 & 13,778 \\
\hline $1983^{a}$ & 3,270 & 850 & 3,250 & 700 & 900 & 8,970 \\
\hline Totals & 11,318 & 4,300 & 12,170 & 4,700 & 3,900 & 36,388 \\
\hline
\end{tabular}

a Figures for 1983 are based on areas proposed for reforestation under IBDF programmes, and not area actually reforested.

Source: Personal communication: Instituto Brasileiro de Desenvolvimento Florestal (IBDF), Delegacia Estadual do Maranhão

several states with strongest impetus during a period in the late 1970s when babassu fruit mesocarp first began to be considered as a potential source of fuel ethanol. None of the attempts to establish babassu plantations have been of notable success. One reason for this is the lack of knowledge of appropriate agronomic techniques for nursery and field planting or management. Recent studies have found that babassu, like most palms, flourish best if first planted under nursery conditions, in polythene bags which allow for the deep root growth characteristic to the species.

Trees are seldom planted for fuel or fencing. Secondary forest fallows provide for most polewood, and babassu husks furnish the major source of cooking fuel in rural areas. The majority of rural households use babassu charcoal as their principal fuel (Table 3).

1.4.3 Agroforestry-type systems/practices. There are two general agroforestry practices involving babassu: (1) palm-pasture; and (2) palm-shifting cultivation. These systems are associated and together cover much of the region. The first involves pastures planted under native palm stands thinned of senescent and unproductive palms; babassu shades cattle, and it protects and replenishes soils. The second involves shifting cultivation within native babassu stands, where babassu leaves provide fuel for the burn, and mature palms are retained over crops to provide a range of subsistence and market products during the fallow cycle $[3,12]$

\section{Structure of the system}

\subsection{Components of Babassu agroforestry systems}

2.1.1 Crops. Shifting cultivation typically consists of intercropped rice (Oryza sativa), maize (Zea mays), cassava (Manihot esculenta) and several 
Table 3. Proportion of rural families using babassu products in Maranhão municípios. $\mathrm{n}=$ Sample size

\begin{tabular}{lllllll}
\hline & \multicolumn{2}{l}{ Percent of families interviewed } \\
\cline { 2 - 7 } Municipio & Thatch & Basketry & Charcoal & Milk & Oil & Palmito \\
\hline $\begin{array}{l}\text { Bacabal }^{\mathrm{a}} \\
(\mathrm{n}=104)\end{array}$ & 86 & 96 & 96 & 44 & 53 & n.a. \\
$\begin{array}{l}\text { Lima Campos } \\
(\mathrm{n}=64)\end{array}$ & 94 & 83 & 92 & 70 & 66 & 8 \\
$\begin{array}{l}\text { São Bento } \\
(\mathrm{n}=57)\end{array}$ & 76 & 72 & 49 & 72 & 74 & 16 \\
$\begin{array}{l}\text { Chapadinha } \\
(\mathrm{n}=98)\end{array}$ & 86 & 90 & 96 & 89 & 91 & 42 \\
Average & 86 & 85 & 83 & 69 & 71 & 22 \\
\hline
\end{tabular}

a Source: [3]

bource: P. May (unpublished data)

bean species under babassu palms. Rice is by far the region's most important crop and is used as a payment for land rental, a cash crop, and a principal source of sustenance. Over 125 regional upland varieties are in use [7]. Maranhão is one of the major rice producing states of Brazil, even with traditional methods. Dried maize is used as feed for animals and rarely sold. Bitter cassava is used for making flour ('dry' or fermented 'farinha d'agua'), which is a basic staple. Cowpeas (Vigna sinensis) and lima beans (Phaseolus lunatus) are also primarily for subsistence consumption. Among other cultivars planted are squashes (Cucurbita spp.); watermelon (Citrulus lanatus); West Indian gherkin (Cucumis anguria), locally known as 'machiche'; okra (Hibiscus esculentus); cucumber (Cucumis sativa); and banana (Musa spp.).

2.1.2 Trees and other woody perennials. Dominant species found in babassuassociated secondary forests and their principal uses are listed in Table 4. Regrowth cycles of secondary forest correspond with long fallow periods of shifting cultivation, after which useful tree species are harvested as polewood or timber during land preparation for cultivation. Other palms, such as carnauba, buriti (Mauritia flexuosa) and tucum (Astrocaryum vulgare) occur in varying abundance in association with babassu, and furnish oils, food, waxes, fibre, and construction materials to rural households.

By far the dominant woody species encountered in these systems is the babassu palm (66\% dominance in 1 ha of secondary forest in the Cocais [2] ). Babassu dominates the landscape due to its cryptogeal mode of germination, in which the growing point (apical meristem) initially grows underground, remaining until the stem emerges several years later. This adaptation permits juvenile palms to survive the cutting and burning associated with shifting cultivation.

According to local farmers interviewed, babassu palms attain fruiting stage 
Table 4. Uses of principal woody species found in babassu agroforestry systems

\begin{tabular}{|c|c|c|}
\hline Species & Local name & Uses \\
\hline Spondias mombim & Cajá & edible fruit \\
\hline Inga spp. & $\operatorname{Ing} \tilde{a}$ & edible fruit \\
\hline Cecropia spp. & Imbauba & $\begin{array}{l}\text { leaves eaten by sloths } \\
\text { (game meat) }\end{array}$ \\
\hline Acacia spp. & Unha de gado & construction, fence posts \\
\hline Tabebuia spp. & Pau d'arco & construction, fence posts \\
\hline Cedrella odorata & Cedro & construction, fence posts \\
\hline Astrocaryum vulgare & Tucum & oil, basketry \\
\hline Mauritia flexousa & Buriti & $\begin{array}{l}\text { edible fruit, thatch, } \\
\text { basketry }\end{array}$ \\
\hline Copernicia prunifera & Carnauba & wax, basketry, contruction \\
\hline Acrocomia sclerocarpa & Macauba & oil, meal \\
\hline Euterpe oleacea & Juçara & palmito, edible fruit \\
\hline Orbignya phalerata & Babaçu & $\begin{array}{l}\text { oil, charcoal, thatch, } \\
\text { feed, basketry, construction }\end{array}$ \\
\hline O. teixeirana & & \\
\hline O. eichleri & Piaçava & basketry, brushes \\
\hline
\end{tabular}

after 10 to 12 years under optimal condition (although there are no controlled trials to confirm this). Adult palms produce a single inflorescence with each new leaf. Panicles contain ca. 200 fruits averaging $190 \mathrm{~g}$ each (range: $80-450 \mathrm{~g}$ ). Fruits are mostly collected from the ground and broken manually by women and children by hitting with a club and breaking the fruit against the upright blade of an axe. Most kernels extracted in this way are sold and the husks used to produce charcoal. The importance of babassu products for the subsistence economy of the region has recently been measured [3, 12] (Table 3).

2.1.3 Animals. Landowners typically have more numerous and varied livestock than their tenants. Prosperous families raise guinea hens, turkeys, ducks and geese, along with pigs, goats and sheep (all consumed by the family and slaughtered during local festivals). Most families have a few chickens; some have mules, donkeys, horses and oxen as beasts of burden. There is very little use of animal traction for cultivation. Small farmers rarely own cattle; those that have a few head frequently rent pasturage rights from landowners at monthly rates which averaged the equivalent of US\$ $2.75 \mathrm{head}^{-1}$ in early 1983 [8]. Animals are fed babassu leaves from juvenile palms, kernel residues, palm heart and mesocarp meal, as well as cassava peelings, corn and crop residue.

Ranchers raise herds of cattle and some water buffalo. Ranchers have been investing gradually in improving their local ' $p e$ é duro' mixed cattle breeds. The preferred cattle species are 'Zebu' and 'Nelore' breeds of Brahman stock, and 'Holandés' dairy cows. Cattle are generally range-fed on native and planted pastures and on young secondary forest regrowth in fallowed cropland. There is little use of silage or stored grains as feed. 


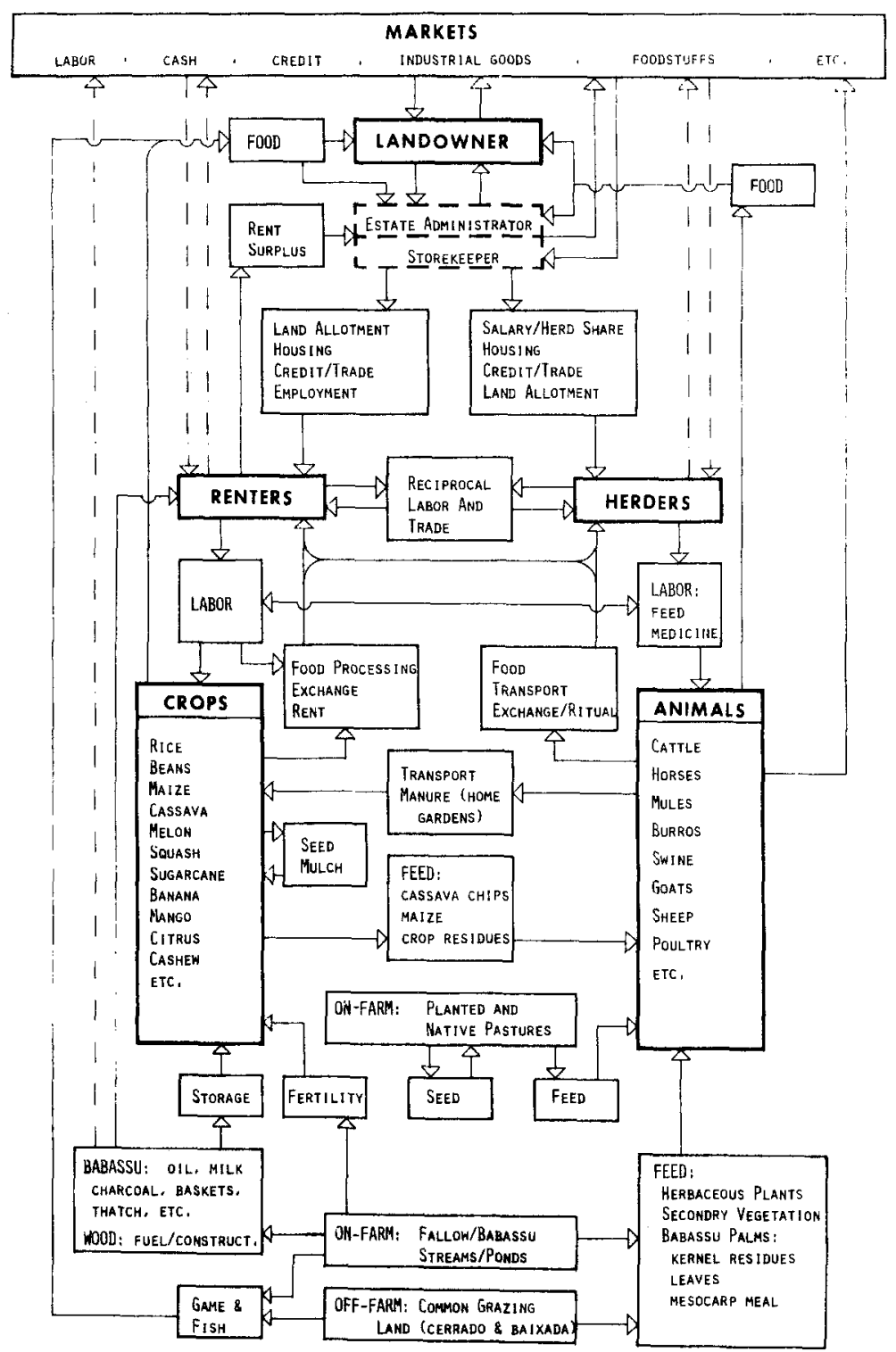

Figure 3. Principal interactions in traditional babassu agroforestry systems in Mid-North Brazil. Drawn by J. Barki based on a diagram by P. May.

Pastures are managed at low stocking rates, seldom exceeding one animal unit per ha. More modernized operations involve pasture rotations. The most popular pasture grasses are jaraguá (Hyparrhenia rufa), colonião (Panicum maximum), and one or more species of Brachiaria. Fodder grasses, particularly elephant grass (Pennisetum purpureum), are also planted in small 
areas, cut into forage and fed to cattle during the dry season, along with cassava chips and babassu oil press cake.

2.1.4 Game and fish. Small farmers rely to considerable extent on hunting and fishing for animal protein. Several large rodent species such as cotia (Dasyprocta punctata) and paca (Agouti paca) abound in the palm forests, feeding on the mesocarp of fallen babassu fruit [14]. Game potential in babassu forests is enhanced by this feed source. Rodents' removal of the mesocarp also appears to stimulate germination in babassu [2] thus making the relationship somewhat symbiotic. Fishing is done in even the smallest freshwater streams. Game animals and fish are cooked in babassu-kernel milk and home-made oil.

2.1.5 Synthesis of traditional systems. Figure 3 schematically describes the composite structure of traditional babassu agroforestry systems following a format developed for descriptions of similarly integrated crop and animal production systems throughout the tropics [13]. This diagram, which is self-explanatory, shows interconnections between different enterprises of landowners and tenants, as well as the social relations of production through which these enterprises function.

\subsection{Arrangements/interaction of components}

In babassu-associated cropping systems, stands are thinned of senescent and unproductive palms to between 50 and 100 adult palms ha ${ }^{-1}$. The leaf biomass in babassu stands is exceptionally high. On a 1 ha site in the Cocais region the leaf biomass totalled $52.7 \mathrm{t}$ dry weight (DW) and an annual leaf production of $16.8 \mathrm{t}$ DW was recorded [2]. A burned stand requires about 4 years to recover its full biomass of leaves. After the annual burn in October, emergent (but still immature) panicles exposed to fire are worthless for kernel extraction, as the liquid endosperm is destroyed by excessive heat. However, productive palms quickly regain productivity and recover completely after approximately 2-3 years, according to local farmers. This occurs because non-emergent inflorescences are protected from fire by heavy leaf sheaths. Cutting of leaves, which is also a common practice to meet the farmers' storage and shelter needs, also serves to increase light penetration during the subsequent growing season.

Harvesting of babassu fruit from fallow sites is a regular aspect of regional farming activities. Fruits commence to mature and drop from the panicle in August, continuing through the beginning of the rainy season in January, when planting of annual crops commences. People continue gathering babassu fruit from the ground during the rest of the crop cycle as a secondary activity, limited by labour requirements in weeding and harvesting annual crops, as well as reduced accessibility of stands due to flooding.

In the crop field, farmers plant rice densely in holes about $20 \mathrm{~cm}$ apart 


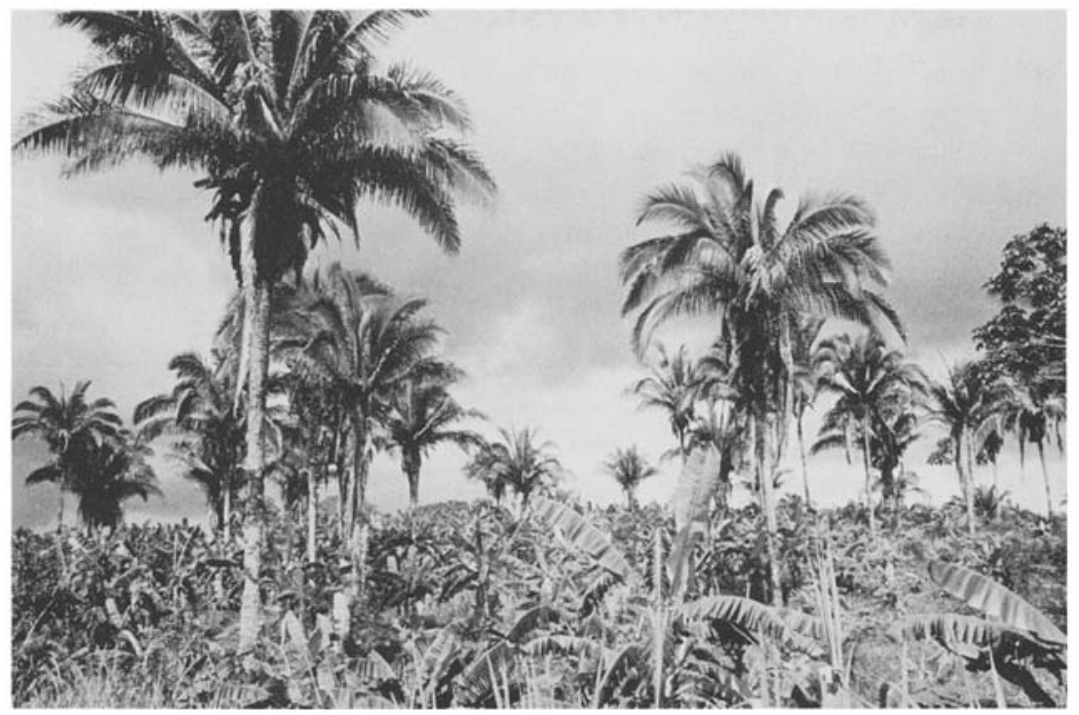

Figure 4. Bananas growing under babassu palms in Lima Campos, Maranhão. Photograph by P. May

and maize in hills in rows up to $2 \mathrm{~m}$ apart among the rice. Cassava is also planted sometimes between these maize rows. Beans are either planted around maize stalks and babassu trunks, drilled in rows in a separate destumped plot, or scattered in a previously cropped site. Earlier in the season, farmers randomly plant the other crops (e.g., watermelon, okra, squash, etc.) within the annual crop field.

Harvesting of annual crops begins in late March after two manual weedings. Farmers first harvest early rice varieties, green corn and beans for household consumption. Most of the harvest period is devoted to rice cutting, after completion of an average 120-day cycle. Farmers store rice on the sheaf in shelters covered with babassu leaves. After breaking stalks during the rice harvest, maize dries in the field until August to October, when it is harvested and stored as grain. Farmers usually plant additional cassava at the end of the rice harvest, which extends the life of the crop field. Cassava varieties in use typically require up to 18 months to mature, after which household members harvest the tubers as needed for flour production, which peaks in the slack period before new land clearing. Once they harvest the cassava, they abandon the plot to secondary forest fallow dominated by babassu. Banana planted under babassu also extends the life of the cropping system (Figure 4).

In most planted pastures, palms are retained at 50-120 stems ha $^{-1}$. Ranchers also tend to thin unproductive palms. This appears to promote the growth of pasture grasses and increase palm yields. Total fruit productivity of palms per unit area inventoried within 136 blocks in a uniformaged stand on a yellow latosol in the Cocais increased linearly with stand density to about 120 stems $\mathrm{ha}^{-1}$, beyond which growth in yield tended to 
drop-off with increased stand density (Frazão and May, unpublished data). Palm stands with pastures underneath as compared with secondary forest facilitate safer collection of fruits because of reduced undergrowth and the ease of sighting snakes. Ranchers interviewed asserted that pastures under palms retained moisture better and had higher productivity in comparison to open conditions. On the other hand, juvenile palms must be frequently cut back to avert competition with pasture grasses, representing a major cost to the rancher (averaging the equivalent of US\$ $15 \mathrm{ha}^{-1} \mathrm{yr}^{-1}$ for manual cutting). For this reason, some ranchers consider babassu a serious weed problem that they attempt to permanently eradicate with herbicides or soil grading. Suppression of juvenile palms, however, will result in stand degradation of babassu after about 50 years, due to senescence of the remaining palms.

\section{System functioning}

\subsection{Resource input and utilization}

3.1.1 Land. According to the 1980 census [10], fallows and forest account for $66.5 \%$ of agricultural lands in the Cerrado. In the Cocais, pastures dominate $(47.9 \%)$, with proportionally smaller areas in fallow and forest. The landowner allocates land annually to tenants for shifting cultivation at his discretion. Unwritten tenancy contracts involve a fixed rent which represents up to $30 \%$ of average rice yields in traditional intercropping systems for each land unit cultivated by the tenant farmer. Annual shifting cultivation plot areas averaged 1.0 ha in the Cerrado and 2.3 ha in the Cocais in the period 1982-84; this may be lower than normal due to drought (May, unpublished data). Area under crops per household is more for landowners than for tenants, but usually involves similarly rudimentary technology.

3.1.2 Labour. Households average 4 persons, yet express a considerable range in size, and are not stable in composition. This is because active males migrate to mining and urban areas either seasonally or year-round, so there are usually more women, children and older people in permanent residence within landless households. Land preparation (clearing, burning, fencing) is done by adult males. Given labour shortages, the household may employ daily workers ( $50 \%$ of families surveyed used this tactic), or engage in labour exchanges ('troca de dias') with other households to reduce labour costs and assure timely completion of essential tasks. Daily wages averaged US $\$ 1.50$ in 1983-84. Women and children are occupied in babassu fruit collection and breaking during the entire land preparation period (August-December). Agricultural operations in February and March (weeding) and May-June (harvesting) may require more family members to be involved in those so that the quantity of babassu fruit harvested declines during this period.

This pattern of labour allocation ensures the availability of a steady labour 
Table 5. Per capita weekly income by source: average of 75 households in 3 Maranhão municípios, Oct.-Dec. 1983

\begin{tabular}{lrlllrr}
\hline Source & $\begin{array}{l}\text { Cash } \\
\text { Cr\$ }\end{array}$ & $\%$ & $\begin{array}{l}\text { Non-cash } \\
\text { Cr\$ }\end{array}$ & $\%$ & \multicolumn{1}{c}{ Cr\$ } & $\%$ \\
\hline Babassu & 597 & 39.7 & 217 & 26.0 & 814 & 34.8 \\
Non-Babassu & 906 & 60.3 & 617 & 74.0 & 1,523 & 65.2 \\
Totals & 1,503 & 64.3 & 834 & 35.7 & 2,337 & 100.0 \\
\hline
\end{tabular}

${ }^{\text {a }}$ Exchange rates averaged Cr $\$ 1000$ per US $\$$ during this period.

Source: [12]

force throughout the year. Landowners employ their tenants and, at peaks, hire non-resident labourers, whose wages will be paid in cash or kind (usually a fixed amount of the crop harvested, but also in meat; labourers customarily receive a meal as part of their wage). Although no labour obligations to the landowner are built into the tenancy contracts, the estate residents are generally regarded as a reserve labour force that can be called upon when needed. Tenants are also employed in herding landowners' livestock, for which they receive a share of the calves, typically one in every four calved.

3.1.3 Capital. Small farmers accomplish most tasks with help of little more than an axe, a hoe, a sickle, and a machete. Sales of babassu kernel finance the household's cash requirements up to the next harvest (Table 5). Landowners use the cash flow from babassu products resale and other revenues most frequently to invest in the expansion of cattle herd or pasture rather than in mechanization. Nevertheless, there has been considerable growth over recent years in tractor utilization for pasture establishment and management, as well as some mechanization of rice production. These projects have largely been financed by banks and Federal Government subsidies rather than capitalized from revenues of current production.

3.1.4 Inputs. Chemical fertilizers are rarely used in crop production, though most producers use manures and decomposed babassu stems as a planting medium for kitchen gardens. Pesticides are in more frequent though sparing use. Many rely on spells and prayer to ward-off crop failure, though these are of little help in combatting the drought cycles which have begun to affect the region from the neighbouring semi-arid zone. Most seed is retained from the previous harvest by farmers who prefer to perform their own seed selection rather than rely on goverment sources. Large landowners have easier access to bank credit than do their tenants, using either land or anticipated production as collateral. The national bank has special credit schemes at low interest rates to help cover small farmers' production costs. Nevertheless, most farmers complain of problems in securing or obtaining timely release of production loans. 
Table 6. Production and value of principal crops and babassu per unit area

\begin{tabular}{llc}
\hline Crop & Average output/ha & Gross value/ha (US\$) \\
\hline Rice (unhulled) & $1.36 \mathrm{t}$ & $\$ 150.40$ \\
Maize (grain) & $0.47 \mathrm{t}$ & 45.37 \\
Beans & $0.31 \mathrm{t}$ & 184.63 \\
Cassava (roots) & $6.40 \mathrm{t}$ & 128.83 \\
Banana & 1,102 bunches & 517.94 \\
Babassu Kernel & $0.14 \mathrm{t}$ & 74.31 \\
Babassu Charcoal & $0.45 \mathrm{t}$ & 26.87 \\
\hline
\end{tabular}

a In April-June 1984 average market prices. Net revenues would be somewhat lower. Sources: $[4,10,13]$ and PH May (unpublished data).

\subsection{Production}

Outputs vary widely among farmers, agro-ecological regions, and over time; average figures are given in Table 6 . They may be slightly biased by output from non-intercropped or mechanized production, which represents a small proportion of overall crop output. Cassava and bananas are successional species in annual crop fields. Babassu output is for normal fallow cycle production of $2 \mathrm{tha}^{-1}$ in average regional stands (fruit yields range from less than 1 to over $6 \mathrm{tha}^{-1}$ ).

$P e ́$ duro cattle breeds raised on the Cerrado seldom achieve marketable beef weight over $100 \mathrm{~kg}$ in 3-5 years at extremely low stocking rates; this output is somewhat lower than the Brazilian average of about $125 \mathrm{~kg}$, most raised on comparably extensive range. Superior breeds raised on improved pastures in the Cocais yield considerably more meat in a shorter period at higher stocking rates, which helps to explain why much of this region is giving way to pasture.

The Mid-North region rarely experiences drought. Abnormally dry rainy seasons between 1980 and 1983 resulted in significant cropland and herd adjustment. Small farmers were unable to save sufficient quantities of seed for planting; to avert risk they planted considerably less area than normal. Sale of babassu kernel and off-farm income were crucial to maintain household income.

\subsection{Protective and service aspects}

Besides a number of important subsistence products such as thatch and basketry, babassu leaves contribute to the sustainability of shifting cultivation systems. Given a long enough fallow period, babassu leaf biomass provides sufficient fuel and nutrients so that mature palms may be retained when clearing secondary forests for crop production. High leaf productivity enables shifting cultivators to return to the same site within four or five years. In addition, microclimate conditions under palms may promote moisture retention in soils. On hillsides, palms appear to prevent soil erosion, both through crown protection against exposure to erosivity caused by direct 
rainfall and root binding of soils. Utilization of babassu fruit husks for charcoal reduces deforestation pressure on other woody species that would otherwise be used as fuel sources.

\subsection{Socio-economic description}

Small farmers incur mounting indebtedness during the period between harvests. Capital peaks at the termination of the rice production cycle in July. Cash flow derived from babassu kernel sale is fairly constant from September through January, providing an important supplement to stored grain. When goods stored from the harvest and babassu income become insufficient, goods are purchased on credit from landowners and local shopkeepers. This debt is sometimes not fully defrayed at harvest time. This creates strong dependency relationships which go beyond purely economic ties to the landowner or other source of credit. Formal organization among small tenant farmers is minimal, probably due to their fragmentation and dependency on their landlords. Rural workers' unions have been formed, attempting to assure job security for wage workers and to mediate land title disputes between smallholders and speculators. Such disputes are particularly severe in the PreAmazonic region, where squatters are losing battles to secure legal title.

\section{System dynamics}

\subsection{Rate of growth - expansion/degradation}

The historical growth in babassu kernel production is directly related to population increase and frontier expansion in the region. Migration from drought-stricken and mechanizing areas of Northeast Brazil swelled Maranhäo's population by 430,000 between 1950-1970. Land use change and rural employment shifts have affected areas of the babassu zone at different times. During the 1960s, the Cocais was the area of most rapid population growth; during the 1970s, the highest growth rates were observed in the Pre-Amazonic region. Conversion to pasture in the Cocais forced many small farmers to migrate to the west where there were then relatively more free lands. Accompanying this migration has been a gradual expansion of babassu stands into the Pre-Amazonic region, as primary forests are cleared for shifting cultivation.

The amount of land available for shifting cultivation has been reduced by widespread conversion to pasture, resulting in a decline in productivity of crops as well as of babassu palms, in areas remaining available for cultivation. With degradation of shifting cultivation sites, the rural poor are becoming increasingly dependent on pasture stands of babassu as a source of income and subsistence products. Despite its beneficial attributes, ranchers often treat babassu as marginal to their overall enterprises. People who gather babassu fruits are perceived as interfering with pasture management, being 
blamed for starting wildfires, cutting fences, and leaving behind fragments of fruit husks that can cause injury to the hooves of cattle. To rid themselves of such incursions, ranchers are increasingly clearcutting the palm forests.

Ranchers who receive government subsidies for pasture establishment are encouraged to remove native forest, which in practice represents a further incentive to clear babassu. From 1967-1980, 72 such projects were approved for financing in Maranhão alone, on an area totalling over 1 million ha [1]. Babassu stands are also being felled to make way for mechanized rice operations, as well as plantations of sugarcane and bamboo.

These projects correspond with national efforts to stimulate agricultural exports to service international debt or substitute for imported fuels. Babassu, an indigenous plant resource of considerable local economic significance, is being substituted by export crops from the region. Though state laws prohibit clearcutting of babassu in an attempt to preserve moderate densities of palms in pasture systems, these laws are unenforceable. We suspect that the rate of deforestation is increasing exponentially in more humid and fertile areas, due to the combined pressures of pasture conversion, breakdown of shifting cultivation, and establishment of permanent agricultural systems.

\subsection{System sustainability}

The future role of babassu in regional farming systems largely depends on the attitudes of the people who own and manage the land. In regions where land uses are intensifying such as the Cocais and Parnaiba Valley, the palm is often considered marginal due to its low yields and slow growth. In these relatively fertile areas, babassu's continued dominance of the landscape appears to be seriously threatened. Yet the palm has shown a remarkable capacity to recover and eventually dominate landscapes where intensive forms of land use were practised in the past.

In drier, less fertile areas, such as the Cerrado region in Maranhão and most of the babassu zone of Piaui, the palm is still an integral part of traditional land use systems and will probably remain so.

\section{Evaluation}

\subsection{Merits}

The productive and service functions of babassu in traditional systems are ranked as follows:

1. Babassu is an important source of vegetable oil and feed cake and has considerable unrealized potential to supply fuels as well as other industrial products such as starch and tar.

2. Cash income from sale of babassu products (principally kernels and charcoal), constitutes a significant share of small farmers' income obtained during the period between harvests of annual crops. This income, which is 
generated principally by women and children whose labour is not critical to agricultural activities in the land preparation phase, strongly complements that derived from other activities and provides a risk cushion in the event of crop failure.

3. A wide variety of subsistence products, consisting chiefly of charcoal, thatch, basketry, edible oil and food products, feed and fodder is obtained from the palm by small farm families.

4. High biomass production provides farmers with sufficient material for fuel in shifting cultivation systems, without requiring drastic thinning of the stands.

5. Land coverage by babassu palms appears to promote soil moisture retention and improve pasture productivity, as well as providing shade for cattle.

\subsection{Weaknesses/constraints}

1. Low current fruit productivity in wild stands of babassu leads to their replacement with open pastures, mechanized crop production and even other trees.

2. Pasture encroachment diminishes land available for shifting cultivation, and reduces the duration of fallow cycles, which compel shifting cultivators to drastically thin or clearcut the very palm stands on which they depend for a sizeable share of their incomes.

3. Ranchers consider juvenile palms noxious weeds that compete with pasture grasses due to their capacity to survive cutting and burning.

4. Stands maintained over pastures are subject to gradual deterioration as new growth is suppressed.

5. Utilization of existing stands for kernels accounts for only about $30 \%$ of total fruit production, due to low value of product, inaccessibility, and prohibition against collection.

6. Efforts to develop technology for processing whole babassu fruit and marketing them threaten to reduce employment and subsistence benefits from the existing cottage industry.

7. Inequitable land distribution constrains the prospects for developing babassu-based agroforestry systems.

\subsection{Potentials}

1. Babassu's attributes as providor of a wide range of products, its ease of establishment and maintenance, and its current close integration with extensive production systems on marginal lands could be enhanced by a breeding programme to upgrade productivity of apparent natural hybrids of babassu with palms such as inajá (Maximiliana maripa) and piassava (Orbignya eichleri) to select strains more tolerant of dry and nutrient-poor soils.

2. Babassu palms could be retained on hillsides in fertile regions as a means of preventing soil erosion; increased market demand for whole babassu 
fruits will make this attractive to landowners.

3. There is a potential for stand and yield improvement through dissemination of secd from prolific stands encountered in the wild, or genetically improved strains. For example, there are reports of babassu fruits containing up to $17 \%$ kernel, in contrast with the average of $7 \%$; exploitation of such strains for oil would prove advantageous. Corresponding variations have been noted in fruit size, endocarp weight, and hardness, all of which affect industrial viability. From the farm production perspective, recent fieldwork in Pirapora, Minas Gerais has identified babassu palms demonstrating yields $500 \%$ higher than average yields in the Mid-North region (M Balick, J Frazão, J Costa, J Veira, unpublished data). Occurring in a palmpasture combination, this population of a distinct species (Orbignya oleifera) was estimated to produce ca. $10000 \mathrm{~kg}_{\text {fruit }} \mathrm{ha}^{-1} \mathrm{yr}^{-1}$.

4. Available technology for mechanical processing of whole babassu fruits can be scaled-down to the level of the producer; fruit components can be more completely utilized within the farm system, for feed, fuel and fibre, with kernels and charcoal still being supplied to regional industries. With such a technology, part of the estimated $70 \%$ of fruit output that is currently underutilized could become economically harvestable.

\subsection{Extrapolability}

Babassu-related agroforestry practises with present productivity levels show greatest promise in areas having marginal soils and sparse population, where the palm's multiple products can contribute to diversified shifting cultivation and pastoral farming systems. With crop improvement efforts already underway, the palms also are promising as fuel; food and fibre generating components of more intensive production systems in a wide range of tropical environments.

\subsection{Research needs}

1. Highest in priority should be a focus on the potential of apparent natural hybrids of babassu with inaja and piassava for reforestation of marginal areas. This would involve selection of seed from promising native stands or individuals, development of seed propagation techniques, and testing of growth performance on representative soils.

2. Development of technology for processing babassu fruit at the farm level would involve engineering studies to scale-down available peelingseparating-breaking equipment and adapting locally available charcoal kilns to facilitate recuperation of tar. Such developments should go hand-in-hand with market research to identify potential users of non-traditional babassu products, and study of alternative organizational and financial arrangements for fruit collection and processing.

3. Continuing research is needed on management of native stands, and studies of the most efficient crop and pasture species combinations in a 
farming systems context. Trials examining the palm's productivity response under varying levels of soil fertility and water availability are also needed to serve as the basis for recommendations regarding appropriate environmental conditions to speed growth to maturity, improve the ratio of female to male inflorescences as well as the number of palms bearing fruit and the number of panicles per tree.

4. Since many factors affecting productivity appear to be genetically determined in babassu, research is needed to distinguish between environmental and genetic conditions affecting characteristics important to industry such as kernel content. To do so, seed specimens from prolific populations such as that of Orbignya oleifera in Pirapora, Minas Gerais described above must be secured before the palms are cut for crop and pasture development, a real threat in the Pirapora case, whose present population appears to be geographically restricted and endangered, and perhaps comprised of only a few thousand individuals.

\subsection{Data/information base}

The Brazilian National Corporation for Research on Agriculture and Livestock Husbandry (EMBRAPA), through its National Center for Genetic Resources (CENARGEN) and state-level activities in both Maranhão and Piauí has begun a broad-based programme of research and development with babassu and associated palms. A National Babassu Research Programme (PNP-Babaçu) has been established, with staff based in EMBRAPA's Special Unit for State-Level Research (UEPAE) in Teresina, Piauí, responsible for overseeing 9 local projects underway in 1984 on palm phenology, taxonomy, germination and seedling production, and forage combinations, among other concerns [6], and for disseminating results in its publication series. A bibliography on babassu literature has been published [5] as well as a collection of current and historical literature.

CENARGEN, with local resources as well as a USAID grant to the New York Botanical Garden (NYBG) has established an active Babassu Germ Plasm Bank in the Mid-North region, in collaboration with EMBRAPA staff and state agencies in Maranhão and Piauí. Specimens collected from other parts of Brazil and Latin America have been planted as a base for genetic improvement. Voucher specimens for seed are also retained in CENARGEN headquarters in Brasilia, at the Museu Goeldi in Belém, and at the NYBG.

Data on babassu phenology, taxonomy, ecology and utilization were obtained recently by Anderson [2, 3]; economic study of babassu agroforestry systems is currently being carried out by the senior author who may be contacted for further information.

\section{Acknowledgement}

Permission, technical assistance and logistical support for the authors' fieldwork were provided by Brazil's Conselho National de Pesquisa Cientifica e 
Tecnológica (CNPq), the Centro Nacional de Recursos Genéticos CENARGEN and the PNP-Babaçu (based at the UEPAE de Teresina, Piauí) of the Empresa Brasileira de Pesquisa Agropecuária - EMBRAPA, and the Instituto Estadual do Babaçu of Maranhão. All authors received financial support through a USAID grant to the New York Botanical Garden. Additionally, Anderson's research was supported by the U.S. Forest Service, Consortium for the Study of Man's Relationship with the Global Environment; Balick's by the Charles A. Lindbergh Fund, the Joyce Mertz-Gilmore Foundation, and the H. John Heinz III Fund of the Pittsburgh Foundation; and May's by the National Science Foundation, Inter-American Foundation, the NYBG Institute of Economic Botany (with USAID assistance) and the Scott Paper Company Foundation.

The authors also acknowledge the contributions made by Suely Anderson, Herculano Carvalho, Lidio Coradin, Tadeu Costa, Dalmo Giacometti, Linda Gondim, Warwick Kerr, Eduardo Lleras, Mariano Mendes, Wilson Milfont, Pedro Pick, Claudio Pinheiro, Darrell Posey and Ghillean Prance. Dennis Johnson, (Consultant, 3311 Stanford St., Hyattsville, MD 20783, USA) and P.K.R. Nair (ICRAF, Nairobi) thoughtfully reviewed successive drafts of this article.

This modest effort is dedicated to the hundreds of families who participated in the surveys, contributed data, and provided hospitality to the authors.

\section{Acknowledgements}

Permission, technical assistance and logistical support for the authors' fieldwork were provided by Brazil's Conselho Nacional de Pesquisa Cientifica e Tecnológica (CNPq), the Centro Nacional de Pecursos Genéticos CENARGEN and the PNP-Babaçu (based at the EUPAE de Teresina, Piaui) of the Empresa Brasileira de Psquisa Agropecuária - EMBRAPA, and the Instituto Estadual do Babaçu of Maranhäo. All authors received financial support through a USAID grant to the New York Botanical Garden. Additionally, Anderson's research was supported by the U.S. Forest Service, Consortium for the Study of Man's Relationship with the Global Environment; Balick's by the Charles A. Lindbergh Fund, the Joyce Mertz-Gilmore Foundation, and the H. John Heinz III Fund of the Pittsburgh Foundation; and May's by the National Science Foundation, Inter-American Foundation, the NYBG Institute of Economic Botany (with USAID assistance) and the Scott Paper Company Foundation."

The authors also acknowledge the contributions made by Suely Anderson, Heculano Carvalho, Lídio Coradin, Tadeu Costa, Dalmo Giacometti, Linda Gondim, Warwick Kerr, Eduardo Lleras, Mariano Mendes, Wilson Milfont, Pedro Pick, Claudio Pinheiro, Darrell Posey and Ghillean Prance. Dennis Johnson, (Consultant, 3311 Stanford St., Hyattsville, MD 20783, USA) 
and P.K.R. Nair (ICRAF, Nairobi) thoughtfully reviewed successive drafts of this article.

This modest effort is dedicated to the hundreds of families who participated in the surveys, contributed data, and provided hospitality to the authors.

\section{References}

1. Amaral Filho J (1983) A economica política do babaçu: um estudo da extratoindústria do babaçu no Maranhão e suas tendências. Masters thesis, Depto de Economia, Universidade Federal de Pernambuco, Recife

2. Anderson A (1983) The biology of Orbignya martiana (Palmae), a tropical dry forest dominant in Brazil. Unpublished PhD Dissertation, Botany Dept, University of Florida, Gainesville

3. Anderson A and Anderson E (1983) People and the palm forest: biology and utilization of babassu forests in Maranhão, Brazil. Gainesville, Florida: University of Florida

4. CEPA-MA (1984) Preços recebidos pelos produtores, segundo trimestre de 1984. São Luís: Comissão Estadual de Planejamento Agrícola - SEPLAN

5. EMBRAPA $(1981,1983)$ Bibliografia sinelêtica do babaçu. 2 vols. Teresina: UEPAE de Teresina, Piaú

6. EMBRAPA (1984) Babaçu: programa nacional de pesquisa. Brasîia: Departamento de Difusão de Tecnologia, EMBRAPA

7. Fonseca J, Rangel B, Bedendo I, Marques P, Guimarães E and Coradin L (1982) Características botânicas de cultivares e raças regionais de arroz (Oryza sativa L.) coletadas no estado do Maranhão. Brasillia: EMBRAPA-CENARGEN

8. Fundação Getulio Vargas (1984) Preços médios: agropecuária, primeiro semestre de 1983 (Maranhão). Rio de Janeiro: Centro de Estudos Agrícolas, IBRE/FGV

9. Golfari L and Caser R (1977) Zoneamento ecolôgico de regiâo Nordeste para experimentação florestal. Belo Horizonte: Centro de Pesquisas Florestais da Região do Cerrado

10. IBGE (1980) Censos agropecuária de 1980 - Maranhão. Rio de Janeiro: Instituto Brasileiro de Geografia e Estatística

11. IBGE (1983) Anuário estatístico 1982. Rio de Janeiro: Instituto Brasileiro de Geografia e Estatística

12. May P, Anderson A, Balick M and Frazão J (1985) Subsistence benefits from the babassu palm (Orbignya martiana). Econ Bot 39 (2):113-129

13. McDowell $R$ and Hildebrand $P$ (1980) Integrated crop and animal production: making the most of resources available to small farmers in developing countries. Working Papers, The Rockefeller Foundation

14. MIC/STI (1982) Mapeamento e levantamento do potencial das ocorrências de babaçuais (estados do Maranhão, Piauí, Goiás e Mato Grosso). Brasília: Secretaria de Tecnologia Industrial, Ministerio de Indústria e Comércio

15. Smith N (1974) Agouti and babassu. Oryx 12:581-582

16. Steward J (1963) Handbook of South American Indians. Washington, D.C.: U.S. Government Printing Office 